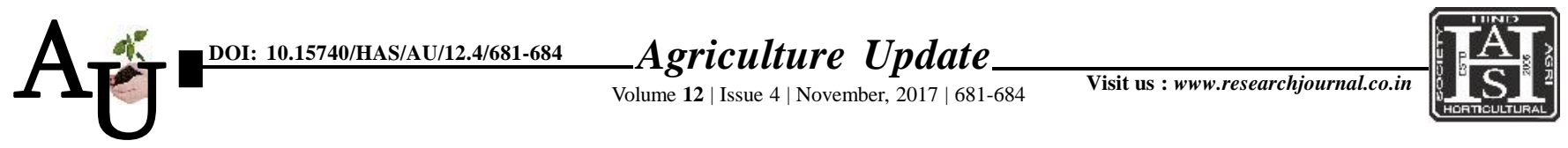

a ISSN-0976-6847

\title{
Research Aвтіcle: Screening of maize genotypes against pink borer, Sesamia inferens Walker under artificial infestation in the field
}

\section{SAILAJA, K. VIJAYA LAKSHMI AND K. LOKA REDDY}

Article Chronicle :

Received :

14.08.2017;

Revised :

29.09.2017;

Accepted :

15.10.2017

KEY Words:

Sesamia inferens,

Maize, Screening

Author for correspondence :

V. SAILAJA

Department of

Entomology, College of

Agriculture, Professor

Jayashankar Telangana

State Agricultural

University,

Rajendranagar,

HYDERABAD

(TELANGANA) INDIA

Email:sailajavallabuni@

gmail.com

See end of the article for

authors' affiliations
SUMMARY : The varietal screening studies of ten maize genotypes were carried out under field conditions with artificial infestation of Sesamia inferens and the classification of the maize genotypes was done based on the dead hearts and leaf injury rating. Among the ten maize genotypes, Madhuri (5.03) was classified as highly resistant genotype, while BML 7 (5.33) was placed under resistant category. The genotype, HKI 163 (5.87) was classified as moderately resistant genotype. The remaining five genotypes viz., HQPM 1 (6.50), MP 717 (6.93), BML 6 (7.03), BH 40625 and BH 1576 (7.90) were grouped as highly susceptible.

How to cite this article : Sailaja, V., Lakshmi, K. Vijaya and Reddy, K. Loka (2017). Screening of maize genotypes against pink borer, Sesamia inferens Walker under artificial infestation in the field. Agric. Update, 12(4): 681-684; DOI : 10.15740/HAS/AU/12.4/681-684. 